\title{
E-Alert Application In Facing Earthquake Disaster
}

\author{
Apriani $^{1}$, Sandi Justitia Putra ${ }^{2}$, Ismarmiaty ${ }^{3}$, Ni Gusti Ayu Dasriani ${ }^{4}$ \\ 1,2,3,4 computer science, Universitas Bumigora \\ E-Mail: ${ }^{1}$ apriani@universitasbumigora.ac.id; ${ }^{2}$ sandi.justitia@universitasbumigora.a.id; \\ ismarmiaty@universitasbumigora.ac.id; ${ }^{3}$ ayu.areyu@universitasbumigora.ac.id
}

\begin{abstract}
Disaster is a phenomenon that has a destructive effect and arises with or without predictions that always accompany human life. This damaging impact can be in the form of loss of life and / or property loss so that it disrupts the natural and social order. Lombok is one of the islands in the group of islands in West Nusa Tenggara. The island of Lombok is flanked by two large faults, the Flores Back Arc Thrust (FBAT) which extends north of Nusa Tenggara to Bali and Megathrust on the south of Lombok. Seeing from the great potential of earthquake disasters that can occur at any time on the island of Lombok, it is necessary to prepare disaster mitigation well in order to minimize the impact of earthquake disaster risk. From the problems outlined, the researchers plan to create a mobile-based earthquake e-standby application. This study aims to create a mobile-based earthquake e-alert application that can be used to view the latest earthquake information, information for determining the nearest evacuation location and educational media related to earthquake disaster awareness. The stages of the research use the prototype development method with stages, namely the study of literature, collection of needs, data collection, needs analysis, design, prototype implementation, prototype evaluation, implementation and testing and conclusions. The conclusion of this research is the construction of a mobile-based earthquake e-alert application. This application is useful for improving, understanding and public awareness of the risk of earthquake disasters and as an educational media to create disaster resilient communities.
\end{abstract}

Keywords-mitigation,disaster, e-Alert, earthquake, application

Author Korespondensi (Apriani)

Email : apriani@universitasbumigora.ac.id

\section{INTRODUCTION}

Disaster is a phenomenon that has a destructive effect and arises with or without predictions that always accompany human life. This damaging impact can be in the form of loss of life and / or loss of property so that it disrupts the natural and social order. Potential causes of disasters can be grouped into 3 (three) types of disasters, namely natural disasters, non-natural disasters, and social disasters. Natural disasters include earthquakes due to nature, volcanic eruptions, hurricanes, landslides, and drought, forest / land fires due to natural factors, plant pests, epidemics, epidemics, extraordinary events, and space / celestial events. [1] BPBD explained that an earthquake is a shock that occurs on the surface of the earth caused by collisions between the earth's plates, active faults, volcanic activity or rock collapse. [2] In the NTB Regional Regulation on 2014 Disaster
Management it is explained that Earthquakes are sporadic disasters where disasters occur suddenly and cannot be predicted, such as earthquakes. [1]

Lombok is one of the islands in the group of islands in West Nusa Tenggara. Located in the southern position of Indonesia, the island of Lombok is bordered by the island of Bali on the west side, the island of Sumbawa on the east side, the Indian Ocean on the south side and the Java Sea on the north side. The population of Lombok Island is 2,890,490 people (2010 BPS Census) with an area of $4736 \mathrm{~km} 2$. (NTB In Figures 2018).

Indonesia is an earthquake-prone area because it is traversed by a meeting point of 3 tectonic plates, namely: the Indo-Australian Plate, the Eurasian Plate and the Pacific Plate. [3] 


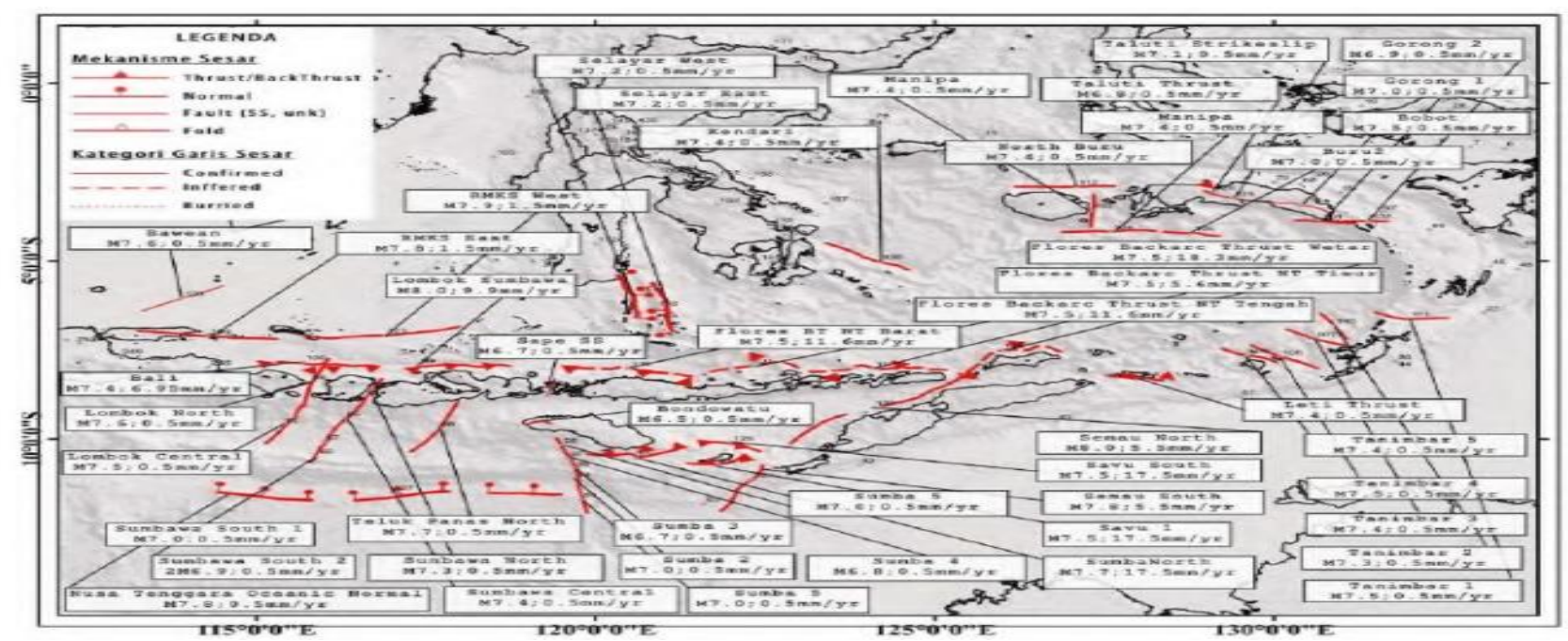

Gambar 1. Sources of Earthquake in NTB and the Surrounding (Supartoyo et al. 2019) [4]

The history of seismicity around the island of Lombok is quite high. The island of Lombok is flanked by two large faults, the Flores Back Arc Thrust (FBAT) which extends north of Nusa Tenggara to Bali and Megathrust on the south of Lombok. The faults are divided into several parts of varying degrees of potential earthquake magnitude. This can be seen from Figure 1 . Where almost the entire potential magnitude displayed has large numbers making it possible for large and destructive earthquakes to occur. Seeing from the great potential of earthquake disasters that can occur at any time on the island of Lombok, it is necessary to prepare disaster mitigation well in order to minimize the impact of earthquake disaster risk. The risks include: (a) Ground shaking; (b) liquefaction; (c) Landslides; (d) Tsunami and (e) Secondary Hazards (short circuit, gas leak which causes fire, etc.). [3]

Mitigation is a series of efforts to reduce disaster risk, through physical development and awareness and capacity building in dealing with disasters [5]. Awareness process is useful so that everyone can make an understanding of the risk, can manage threats and contribute to encourage community resilience from the threat of disaster hazards. One of the things that happened at the time of the earthquake was the panic of the victims of the disaster due to the lack of information and community knowledge about preparedness in dealing with earthquake disasters. Community preparedness in disaster mitigation starts from the prevention and minimization of damage by studying the damage that can occur around the time of an earthquake and providing education and good understanding for local residents in disaster prone areas related to disaster management and possible risks.

Supporting the government in providing a sense of security to citizens, and the mandate of Law Number 36 of 1999 concerning Telecommunications, the National program Nawa Cita is present. it was explained in the Regulation of the Minister of Communication and Information Technology No. 2 of 2016 concerning Submission of Disaster Information through Cellular Mobile Network Operators [6] namely disaster management is not only the responsibility of the government but must be the responsibility of the local communities affected by the disaster. These responsibilities can be in the form of community readiness and intelligence in responding to a disaster [7]. This gives a sense of responsibility to be able to contribute in the field of technology by designing e-standby applications to deal with earthquakes, especially on potential earthquakes on the island of Lombok.

The application is designed using several stages of development which will be explained in the next section. The contents of the application are information on disaster mitigation both in response and mitigation when a disaster occurs, the latest earthquake information, information about the nearest evacuation location and educational media to increase understanding and awareness of disaster risk. The purpose of the research is to 
provide education and information related to earthquake disasters which happened on the island of Lombok.

Some of the literature in previous research that is related, among others, by Addiarto and Yunita (2019) who analyzed the effectiveness of the tabletop disaster exercise media in raising awareness of nursing students in dealing with disasters [8]; Mahfudz (2019) who designed the visual concept of the Yogyakarta Integrated Natural Disaster Mitigation application [9]; Suryadi (2017) designed the Mobile Application for a Safe and Safe Campaign Against the Earthquake and Tsunami in Padang City [10]; Mustiadi and Listyalina (2019) designed the Landslide Early Warning System application for Disaster Risk Reduction [11], Utami and Wibowo (2019) used Spatial Data and Disaster Vulnerability Data as Evaluation of Regional Spatial Planning (post-tsunami case study in Banten) [12]; Sigit Riyadi and Abdur Rokhim (2017) who designed the SMS Gateway based Flood Disaster Response application in the village of Kedawung Wetan Pasuruan [13]; Sulaiman et al. (2019) who carried out the learning of Disaster Preparedness to the People of Bajulmati Hamlet, Gajahrejo Village, Gedangan District, Malang Regency. [14]

Summarizing of these studies, several studies specialize to provide solutions related to disaster mitigation management, some studies namely Addiarto and Yunita (2019) [8] and Sulaiman et al. (2019) [14], specializing in learning the insights of disaster mitigation to the public, other studies are Mahfudz (2019) [9], Suryadi (2017) [10], Mustiadi and Listyalina (2019) [11], Utami and Wibowo (2019) [12] and Sigit Riyadi and Abdur Rokhim (2017) [ 13] try to solve the problem of disaster mitigation through technology by implementing the application of informatics in application design. The strength of this research is that the results of the study will provide information related to the nearest evacuation location which is a long-term anticipatory measure against the possibility of a devastating earthquake and educational media to increase understanding and awareness of disaster risk.

\section{METHODOLOGI}

The research methodology used in making earthquake e-alert applications consists of several stages which can be seen in Figure 2.

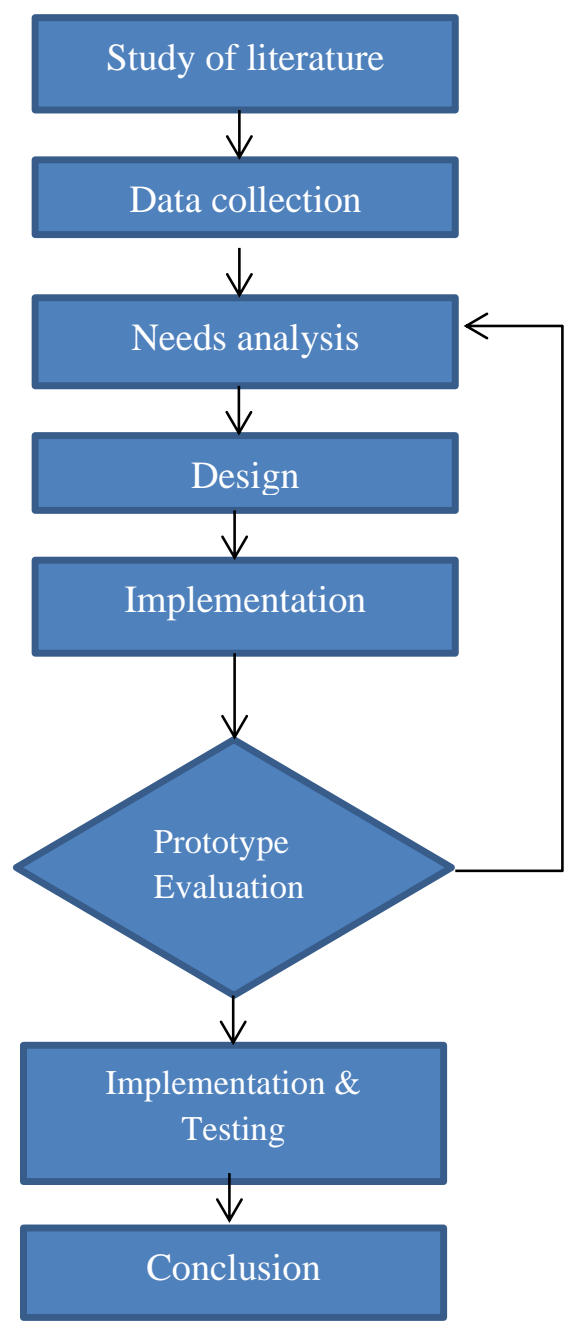

Figure 2. Research Stages

The stages taken in conducting research are the study of literature, data collection, system design, and implementation, testing and drawing conclusions. The first stage in the methodology is to conduct a literature study that is gathering theories from several studies. Next is the data collection stage. The next stage is to analyze the requirements used to obtain software features. The data collection stage can be used as an instrument to analyze needs by using UML which is a type of use case. The next stage is the design in which there is an activity diagram that is the stages of the use case. The stages of design are carried out to identify the classes required in software development. 


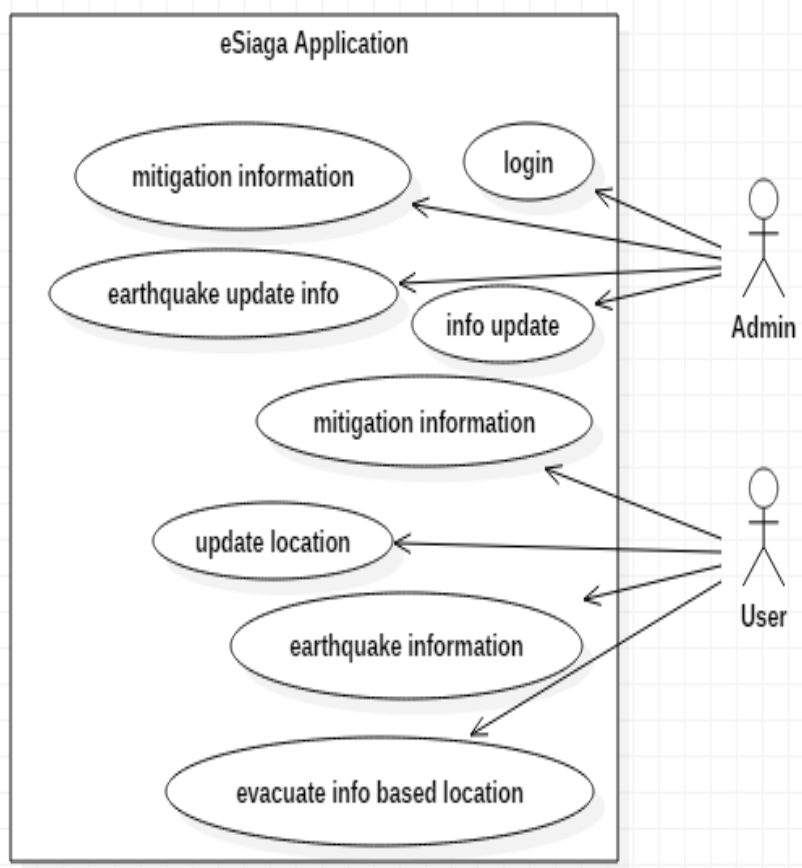

Figure 3.Use Case Diagram

From the identification results are then translated into class diagrams. After identifying the relationship between objects then it converted into sequence diagrams by showing the flow in the system. Next is the prototype implementation stage which will go through the user evaluation process until it meets the user's needs and is used as a reference for system implementation. Next stage is the system implementation stage where the functional features in the application are ready to run. Then the testing phase is used to check whether the functions that exist on the system are functioning properly and in accordance with user requirements.

\section{RESULTS AND DISCUSSION 3.1 Data Collection}

Data needed for research is data taken from the BMKG API (Application Programming Interface), evacuation location sample data and data on preparedness from the National Disaster Management Agency (BNPB). Overall data obtained by searching for available literature on the BMKG portal site, BNPD and other reference data related to disaster mitigation.

\subsection{Tahapan Perancangan Aplikasi}

The stages of application design consist of making use case diagrams, activity diagrams and class diagrams.

\subsubsection{Making a Use case Diagram}

Use case diagrams are used to find out the functions that are in the information system and the use of these functions [15]. Use case diagrams are made to be able to provide general information to users or vendors related to what cases can be done in an application. Display the use case diagram of the application made is in Figure 3.

Figure 3 on the usecase diagram shows that there are two system users namely user and admin. In the admin system users, the admin can $\log$ in which can also manage mitigation information and update information related to earthquake events that occur. In the user user, the user is given features to be able to carry out mitigation information, location updates to adjust information updates, earthquake information and get information related to evacuation to adjust the user's location is located.

\subsubsection{Making Activity Diagram}

Activity Diagram is a description of the work flow of a system contained in the software [15]. The activity diagram of the application made can be seen in Figure 4. 


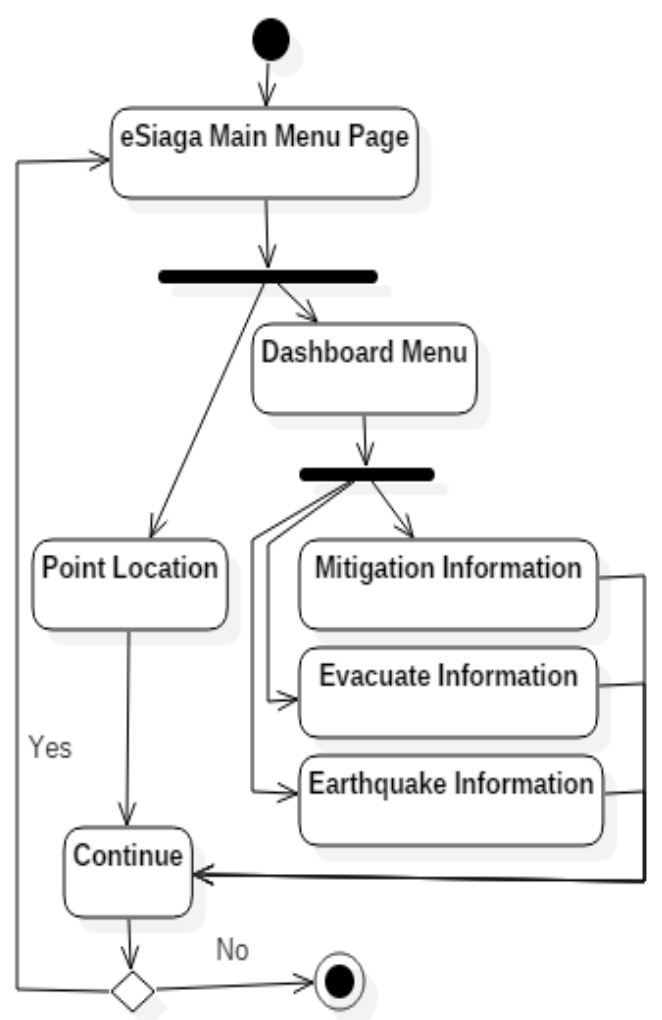

Figure 4. Activity Diagram

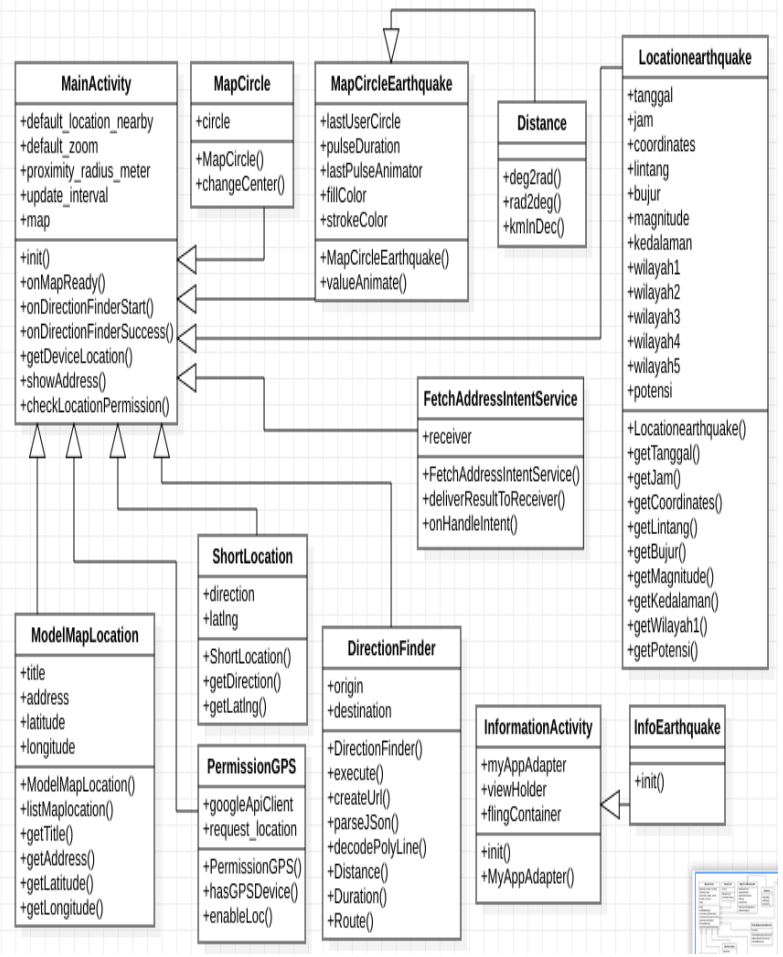

Figure 5. Class Diagram

The activity diagram in Figure 4 shows that the user can activate the disaster alert application by activating the Global Positioning System (GPS) / point location of the mobile and / or viewing information on the menus provided.
This process is carried out to be able to provide information by notifying the user's location so that the system can make settings related to mitigation information based on location. Apart from conducting location points, users can also view information in the application section, namely mitigation information, evacuation information and earthquake information. Those three kinds of information are expected to help users in preparing for disasters, especially earthquakes that cannot be predicted at the time of their occurrence.

\subsubsection{Making Class Diagram}

Class diagram is used to describe the structure of the system in terms of defining the class that will be made to create a system [15]. The class used in the design of an e-alert application facing an earthquake here is a description of the structure of the database used in the application which objectively describes the relationship of the class that is in the application. The Class Diagram is shown in Figure 5.

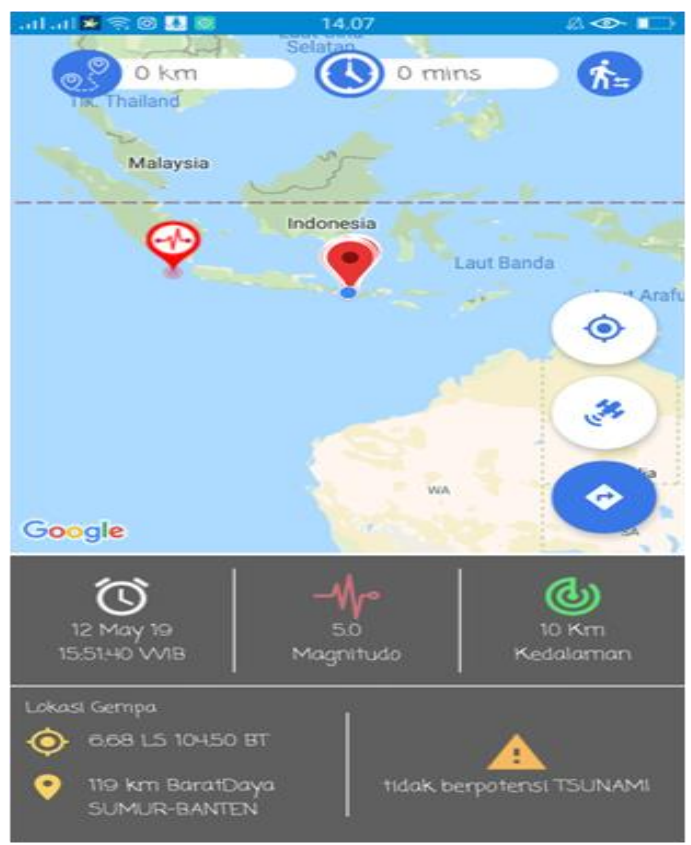

Figure 6. Tampilan Utama Aplikasi E-Siaga

\subsubsection{Prototype Implementation}

The e-alert contains information about the travel time to get to localized evacuation, distance information from the user's location to evacuation location marked with the Blue Point for the location and purpose, evacuation information marked with a red marker, 
earthquake location information, user location information, information about earthquake depth, information about the magnitude of the earthquake shaking, information about the place, date and time of the earthquake and information about the earthquake that has a potential tsunami or not. The display can be seen in Figure 5.

In Figure 6 the user can see several menu options for finding information on responding to disasters in the conditions of Pre-disaster, Disaster and Post-Disaster. The three menus are provided to give clear and detailed information related to disaster mitigation that must be done by the user. The display of disaster response information can be seen in Figures 7, 8 and 9.

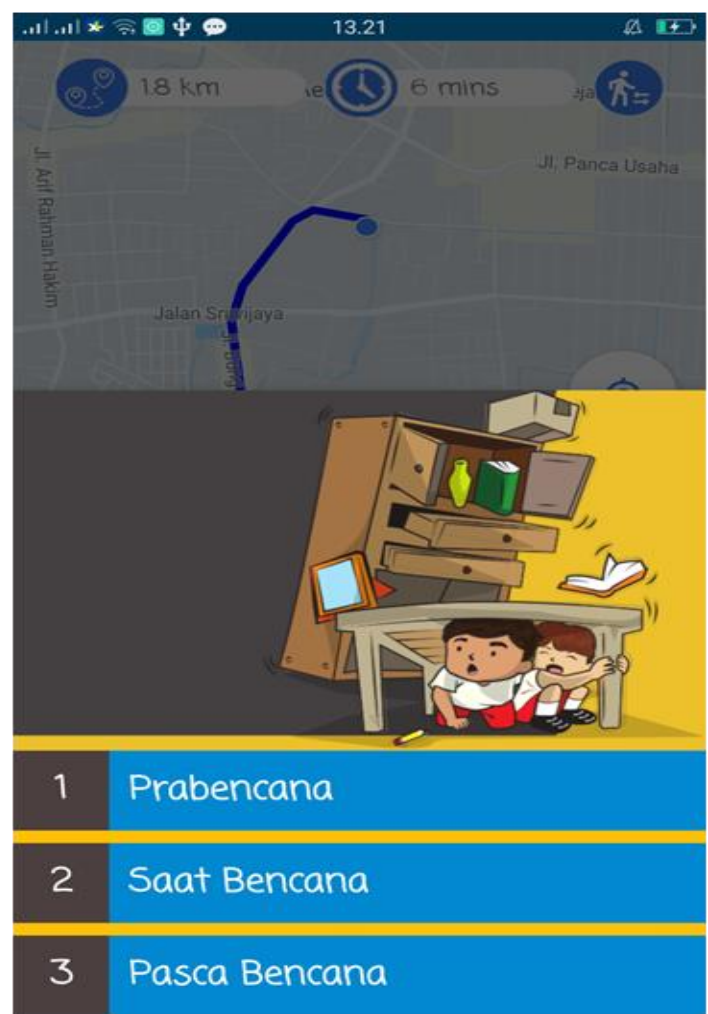

Figure 7. Information on the Pre-disaster, Disaster and Post-Disaster sections

Figure 8 shows the menu contents of the Pre-disaster information section. Pre-disaster information section contains important things that must be prepared before an earthquake occurs. This section provides good education to users related to disaster mitigation matters to minimize the impact of damage that can occur including fatalities.

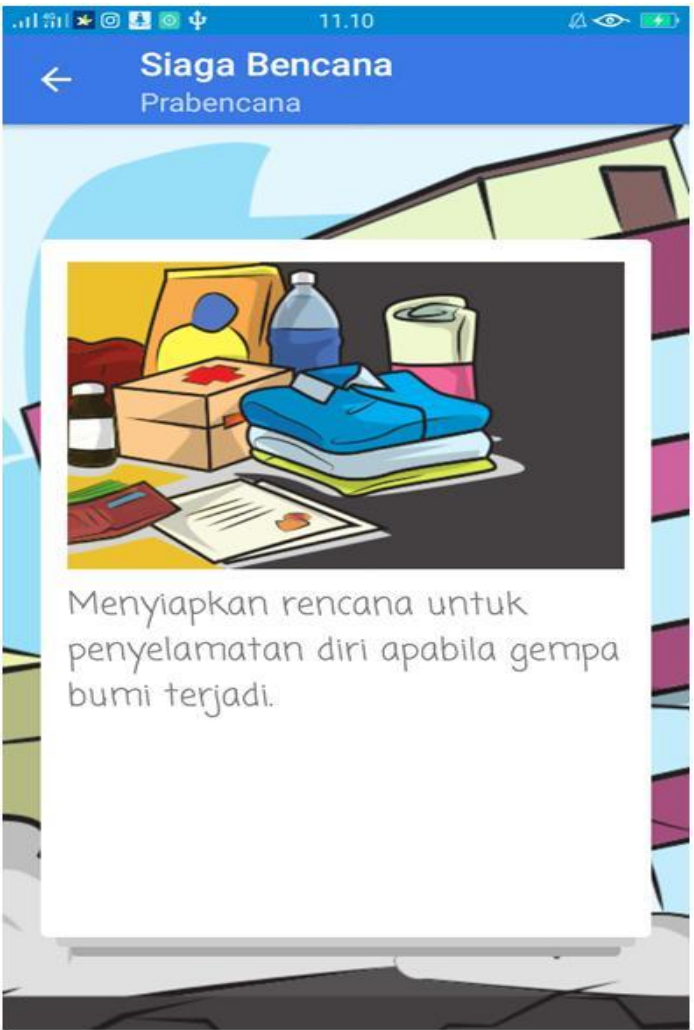

Figure 8. Informasi bagian Prabencana

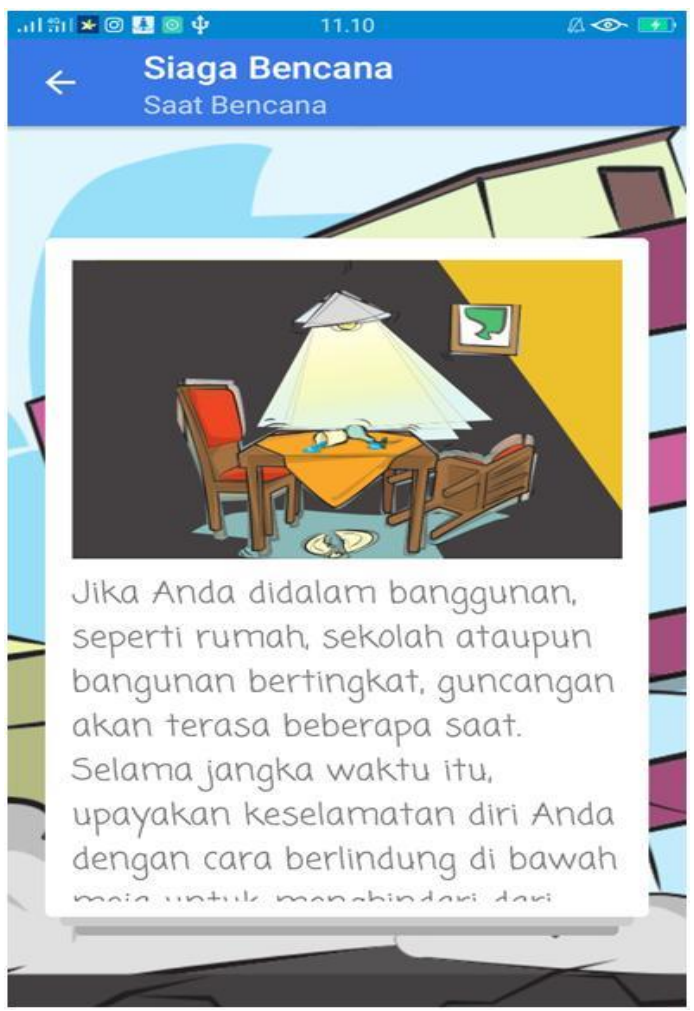

Figure 9. Disaster Information

Apart from information related to predisaster as an anticipatory step to the risk of damage that can be caused by an earthquake. Another menu, which is when a disaster is provided to be able to convey information 
related to disaster mitigation when the disaster occurs. The items presented in this menu are practical and theoretical in relation to the safety of victims of earthquake natural disasters. The display of the system can be seen in Figure 9.

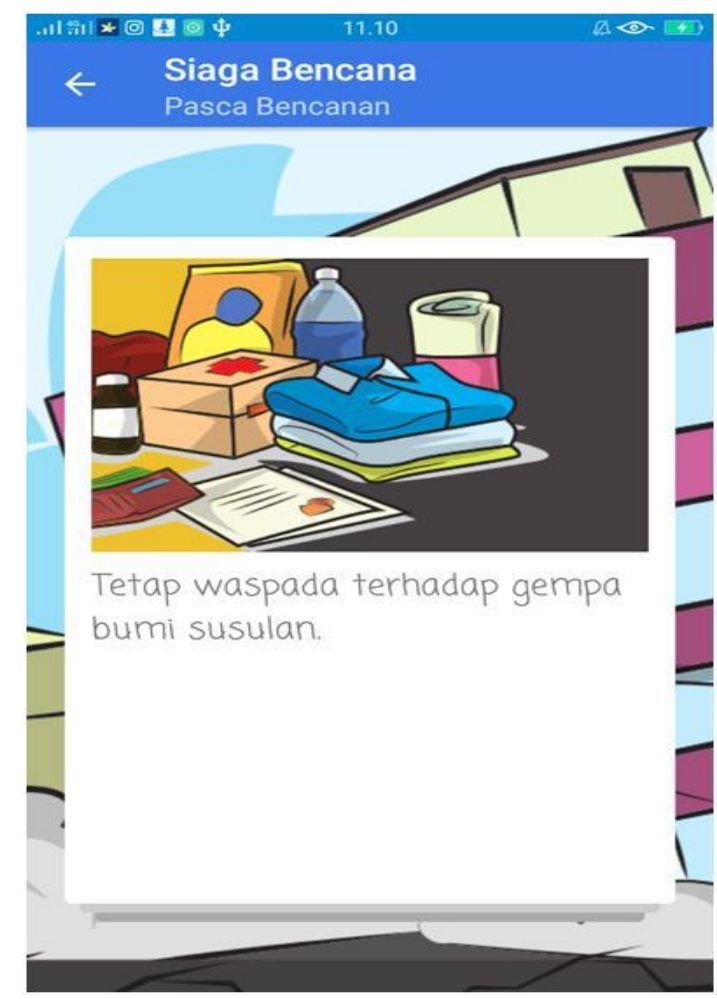

Figure 10.Information after a disaster

Post-disaster information contains things that need to be done when the earthquake disaster has finished, such as staying alert to aftershocks that can come suddenly. This can be seen in Figure 10.

\section{CONCLUSIONS AND SUGGESTIONS}

This study has been built applications based on mobile e-alert.. The e-alert is the answer to existing problems, namely a lack of information and community preparedness in responding to a disaster so that the impact will be greater. The existence of the e-alert application is expected to minimize the impact of the earthquake that occurred. In the development of e-alert, there are some drawbacks, namely the determination of the nearest evacuation point, it just just use the name of the road, it should be added by using the location of the field or the refugee camps that have been defined.

\section{ACKNOWLEDGMENT}

The researcher would like to thank the Directorate of Research and Community Service at the Ministry of Research, Technology and Higher Education for funding of Dosen Pemula Research Grant in 2019.

\section{REFERENSI:}

[1] Penjelasan Atas, Peraturan Daerah Provinsi Nusa Tenggara Barat Nomor 9 Tahun 2014 Tentang Penanggulangan Bencana, 2014.

[2] _ , "Konsep dan Definisi", BPBD (Badan Penanggulangan Bencana dan D, [Online] available: https://bnpb.cloud akses 19 Februari 2020.

[3] __, "Tentang Gempa: Gempa Bumi”, http://balai3.denpasar.bmkg.go.id/ akses 21 April 2020.

[4] Supartoyo dkk, "Analisis Morfotektonik dan Pemetaan Geologi pada Identifikasi Sesar Permukaan di daerah Plampang, Pulau Ngali dan Pulau Rakit, Provinsi Nusa Tenggara Barat", Jurnal Pengembangan Energi Nuklir Vol. 21, No. 12019

[5] Saputra dkk., "Mitigasi Bencana Kebakaran Lahan Gambut berdasarkan Metode Network Analysis Berbasis GIS (Studi Kasus : Pulau Bengkalis), Jom FTEKNIK Volume 4 No. 2 Oktober 2017.

[6] _ "Uji Coba Sistem Penyampaian Informasi Bencana Memanfaatkan SMS Blast”, SIARAN PERS NO.200/HM/KOMINFO/10/2017

[Online] Available: https://www.kominfo.go.id diakses 21 November 2019.

[7] Suyanto, Bagong., "Menyikapi Dampak Bencana Gempa dan Membangun Masyarakat Sadar Bencana", 2018 [Online] Available: http://mediaindonesia.com diakses 19 Juli 2019.

[8] Addiarto dan Yunita" Efektivitas Tabletop Disaster Exercise (TBE) Sebagai Media Simulasi Dalam Ruang Untuk Meningkatkan Kemamouan Triage dan Alur Rujukan Korban Bencana", JI-KES (Jurnal Ilmu Kesehatan) Vol 22019.

[9] Mahfudz, Edy Muhammad Sahal, "Perancangan Konsep Visual Aplikasi Mitigasi Bencana Alam Terpadu 
Yogyakarta" : Skripsi thesis, Fakultas Seni Rupa ISI Yogyakarta, 2019.

[10] Suryadi, Yogi “ Perancangan Aplikasi Mobile Kampanye Selamat dan Aman Terhadap Gempa dan Tsunami Kota Padang": Skripsi thesis, Universitas Negeri Padang, 2017.

[11] Mustiadi dan Listyalina "Aplikasi Landslide Early Warning System untuk Pengurangan Resiko Bencana", Prosiding Seminar Nasional, Universitas Respati Yogyakarta, 2019.

[12] Utami dan Wibowo, "Pemanfaatan Data Spasial dan Data Kerawanan Bencana Sebagai Evaluasi Rencana Tata Ruang Wilayah (studi kasus pasca tsunami di Banten), Prosiding Seminar Nasional, Universitas Respati Yogyakarta, 2019.

[13] Sigit Riyadi dan Abdul Rokhim, "Perancangan Aplikasi Tanggap Bencana Banjir Berbasis SMS Gateway di Desa Kedawung Wetan Pasuruan", Prosiding Snatika (Seminar Nasional Teknologi, Informasi, Komunikasi dan Aplikasinya Vol 42017.

[14] Sulaiman dkk., "Pembelajaran Wawasan Siaga Bencana Kepada Masyarakat Dusun Bajulmati Desa Gajahrejo Kecamatan Gedangan Kabupaten Malang", Jurnal Aplikasi Teknik dan Pengabdian Masyarakat (JATI EMAS) Vol 3 No 1 2019.

[15] A.S Rosa dan M. Shalahuddin, "Rekayasa Perangkat Lunak Struktur dan Berorientasi Obje", Bandung : Informatika, 2014 